\title{
PENGGUNAAN METODE SUGESTI IMAJINASI DALAM PEMBELAJARAN MENULIS CERITA PENDEK
}

\author{
Yulianti $^{1}$, Nuraini Kasman ${ }^{2}$, dan Yusmah ${ }^{3}$ \\ 1,2,3,4 Universitas Muhammadiyah Sidenreng Rappang \\ Jl. Angkatan 45 No 1A Lautang Salo Rappang, Pancarijang, Sidenreng Rappang \\ antuy9207@gmail.com
}

\begin{abstract}
Abstrak: Penggunaan Metode Sugesti Imajinasi dalam Pembelajaran Menulis Cerita Pendek. Tujuan penelitian ini berpengaruh melalui penggunaan metode sugesti imajinasi dalam pembelajaran menulis cerita pendek. Penelitian ini berpopulasi dari keseluruhan jumlah siswa. 39 siswa kelas VIII SMP Negeri 5 panca Rijang yang tersebar dua kelas. Teknik statistik deskriptif dan uji-t digunakan untuk mengolah data sokumen yang diperoleh melalui teknik dokumentasi dan tes tertulis. Kelompok siswa yang diuji melalui menulis cerpen dengan meode sugesti imajinasi dengan nilai rata-rata 80,84 . Siswa yang memperoleh nilai rata-rata 72,10 tanpa menggunakan metode sugesti imajinasi. Hasil analisis uji t. menunjukkan nilai thitung yaitu 3,629 $\geq \mathrm{t}$ tabel 2,026 dengan df 37. Hasil analisis data yang dipeloroleh melalui metode sugesti imajinasi perpengaruh dalam pembelajaran menulis cerpen pada siswa kelas VIII SMP Negeri 5 Panca Rijang semester II tahun ajaran 2020/2021.
\end{abstract}

Kata kunci: Metode, Sugesti Imajinasi, Menulis Cerita Pendek

\begin{abstract}
The Use of Imagination Suggestion Method in Learning to Write Short Stories. The purpose of this research is influential through the use of the suggestion method of imagination in learning to write short stories. This study has a population of the total number of students. 39 students of class VIII SMP Negeri 5 Panca Rijang spread over two classes. Descriptive statistical techniques and t-test were used to process document data obtained through documentation techniques and written tests. The group of students who were tested through writing short stories using the suggestion method of imagination with an average value of 80.84 . Students who get an average score of 72.10 without using the suggestion method of imagination. The results of the $t$ test analysis. shows the $\mathrm{t}$ value is $3,629 \geq \mathrm{t}$ table 2,026 with $\mathrm{df} 37$. The results of data analysis obtained through the suggestion method of imagination influence in learning to write short stories in class VIII students of SMP Negeri 5 Panca Rijang semester II of the 2020/2021 academic year.
\end{abstract}

Keyword: Method, Suggestion Of Imagination, Write Short Stories

Pembelajaran bahasa Indonesia memiliki empat aspek keterampilan dalam berbahasa. Menyimak, berbicara, membaca, dan menulis. Empat aspek berbahasa tidak dapat terpisahkan, keterkaitan yang saling berhubungan. Empat aspek berbahasa, keterampilan yang rumit ialah menulis. Keterampilan menulis yang diharuskan untuk siswa seiring dengan keterampilan berbahasa yang lainnya untuk dikuasai.

Salahsatu kemampuan berbahasa yang dituntut melalui informasi dan pengetahuan yang didapatkan. Hal ini menunjukkan menulis merupakan sebuah proses perkembangan. Oleh karena itu, menulis membutuhkan sebuah pengalaman dan latihan. Kegiatan menuangkan ide atau gagasan dalam bentuk tulisan disebut menulis. Menulis salah satu cara untuk menuangkan perasaan yang merupakan sarana pengungkapan diri. Seseorang dapat menyampaikan pesan atau informasi dengan menggunakan tulisan sebagai media (Suparno dan Yunus, 2007: 4). Keterampilan menulis mampu menuangkan ide, gagasan, pikiran, perasaan, serta kemampuan melalui bahasa secara tertulis. 
Pembelajaran sastra merupakan salah satu keterampilan yang digunakan untuk meningkatkan keterampilan menulis siswa. Pembelajaran sastra bagian dari pembelajaran bahasa Indonesia. Pembelajaran yang penting diajarkan disetiap jenjang pendidikan. Pembelajaran sastra tidak hanya membuat siswa mengenal, memahami, menghafal defenisi sastra dan sejarah sastra. Tetapi membantu siswa untuk mengetahui kemampuannya dalam berimajinasi.

Drama, prosa, dan puisi merupakan jenis-jenis karya sastra. Bentuk karya sastra yang paling banyak digemari adalah karya sastra prosa khususnya cerpen. Salah satu keterampilan berbahasa yang dapat mengembangkan imajinasi dan kepekaan hati seorang siswa ialah cerita pendek. Oleh karena itu, menulis cerpen sangat penting dipahami oleh siswa.

Kenyataan di lapangan menunjukkan bahwa kemampuan siswa menulis cerita pendek masih kurang. Hal ini disebabkan karena beberapa siswa merasa sangat terbebani jika diminta untuk menulis cerita pendek, karena menganggap bahwa menulis merupakan salah satu tugas yang sulit dan membosankan. Adapun kendala yang ditemukan siswa dalam menulis cerita pendek antara lain, siswa kesulitan merangkai kata-kata, sulit menemukan ide cerita dan sulit mengembangkan ide cerita.

Permasalahan tersebut terjadi karena penggunaan metode pembelajaran yang kurang tepat digunakan oleh guru.

Untuk memecahkan masalah tersebut penulis memilih metode pembelajaran yang imajinatif dan efektif. Dengan adanya metode pembelajaran siswa diharapkan lebih termotivasi untuk lebih aktif dalam mengikuti pelajaran.

Metode pembelajaran merupakan bagian terpenting dalam melaksanakan proses belajar. Pembelajaran sebaiknya dilaksanakan dengan cara menarik yang mampu meningkatkan minat siswa untuk mengikuti pembelajaran. Metode merupakan salah satu cara atau strategi yang ditempuh guru dalam proses pembelajaran yang hendak dicapai, semakin tepat metode yang digunakan oleh seorang guru maka pembelajaran akan semakin baik.

Metode dalam pembelajaran diharapkan memberikan efek positif bagi guru dan siswa. Salah satu metode pembelajaran yang digunakan untuk meningkatkan keterampilan siswa dalam menulis cerita pendek ialah metode sugesti imajinasi.
Trimantara (2005:3), metode sugesti imajinasi adalah metode pembelajaran menulis dengan cara memberikan sugesti melalui media lagu untuk merangsang imajinasi siswa. Penyajian lagu dianggap cocok dalam penggunaan metode sugesti imajinasi, karena lagu tidak hanya digunakan untuk menciptakan suasana, stimulus, dan sekaligus menjadi jembatan bagi siswa untuk membayangkan, menggambarkan suatu kejadian atau peristiwa berdasarkan tema lagu. Karena lagu dapat mengubah suasana hati siswa, mengubah keadaan mental siswa, mendukung lingkungan belajar, dan membantu siswa belajar lebih baik.

Untuk mencapai hasil dan prestasi dalam menulis cerita pendek dibutuhkan sebuah proses dan kegiatan yang dilakukan secara terus menerus. Dengan menggunakan metode sugesti imajinasi dianggap cocok untuk pembelajaran menulis cerita pendek, karena metode sugesti imajinasi menawarkan pembelajaran yang menekankan pada proses dan hasil. Penggunaan metode sugesti imajinasi diarahkan menuju target yang hendak dicapai yaitu, sugesti untuk merangsang daya imajinasi siswa.

Harapan penulis terhadap penggunaan metode sugesti imajinasi dalam pembelajaran menulis cerita pendek yaitu, dapat mempermudah siswa dalam menemukan dan mengembangkan ide-ide mereka berdasarkan sugesti yang diberikan. Sugesti yang diberikan oleh guru akan membantu siswa untuk lebih mudah menyusun imajinasi dan gagasannya menjadi sebuah tulisan. Sugesti dapat membantu membuka kembali pengalaman yang telah dimiliki siswa sehingga mereka dapat menuliskannya menjadi cerita yang menarik.

Berdasarkan hal tersebut peneliti tertarik untuk melakukan penelitian dengan memberi judul "Penggunaan Metode Sugesti Imajinasi Dalam Pembelajaran Menulis Cerita Pendek Siswa Kelas VIII SMP Negeri 5 Panca Rijang".

\section{METODE}

Pendekatan yang akan digunakan dalam penelitian ini adalah pendekatan kuantitatif. Penelitian ini menggunakan pendekatan kuantitatif karena fokus dari penelitian ini adalah untuk mengetahui pengaruh penggunaan metode sugesti imajinasi dalam pembelajaran menulis cerita pendek siswa kelas VIII SMP Negeri 5 Panca Rijang. 
Desain yang digunakan dalam peneltian ini adalah desain eksprimen. Eksprimen adalah suatu metode penelitian yang digunakan untuk mencari pengaruh perlakuan tertentu terhadap yang lain dalam kondisi yang terkendalikan (Sugiyono, 2014: 107). Dalam penelitian ini terdapat dua variabel yang akan diteliti. Variabel pertama adalah variabel bebas yaitu metode sugesti imajinasi $(\mathrm{X})$ dan variabel kedua adalah variabel terikat yaitu, pembelajaran menulis cerita pendek siswa kelas VIII SMP Negeri 5 Panca Rijang (Y).

Pada penelitian ini, penarikan sampel menggunakan teknik simpel random sampling. Teknik simpel random sampling dilakukan karena pengambilan anggota sampel dari populasi dilakukan secara acak tanpa memperhatikan yang ada dalam populasi (Sugiyono, 2014: 82). Dengan menggunakan teknik random sampling terpilih satu kelas sebagai kelompok eksprimen dan satu kelas sebagai kelompok kontrol.

Tabel 1 Keadaan Sampel

\begin{tabular}{cccc}
\hline No. & Kelas & Kelompok & Jumlah Sampel \\
\hline 1. & VIII A & Eksprimen & 19 \\
\hline 2. & VIII B & Kontrol & 20 \\
\hline & & Jumlah & 39 \\
\hline
\end{tabular}

Teknik pengumpulan data dalam penelitian ini menggunakan teknik dokumentasi dan teknik tes. Kedua teknik pengumpulan data ini dianggap relevan dengan permasalah dan variabel yang akan dikaji dalam penelitian ini.

Dokumentasi merupakan pengambilan pengambilan gambar yang dilakukan oleh peneliti untuk memperkuat hasil penelitian. Dokumentasi bisa dilakukan dengan berbagai bentuk seperti pengambilan tulisan, gambar atau karya-karya monumental dari sesorang (Sugiyono, 2014: 329).

Teknik tes dilakukan untuk memperoleh data dalam pembelajaran menulis cerita pendek.

Tabel 2 Rubrik Penilaian Menulis Cerpen

\begin{tabular}{clc}
\hline No & \multicolumn{1}{c}{ Aspek yang dinilai } & $\begin{array}{c}\text { Skor } \\
\text { maksimal }\end{array}$ \\
\hline 1. & Kesesuaian tema dan amanat & 10 \\
\hline 2. & Tokoh dan penokohan & 20 \\
\hline 3. & Alur & 20 \\
\hline 4. & Latar & 10 \\
\hline 5. & Diksi atau gaya bahasa & 10 \\
\hline
\end{tabular}

\begin{tabular}{llc}
\hline 6. & Sudut pandang & 10 \\
\hline 7. & $\begin{array}{l}\text { Kepaduaan unsur-unsur } \\
\text { pembentuk cerpen }\end{array}$ & 20 \\
\hline \multicolumn{2}{c}{ Jumlah (N) } & 100 \\
\hline
\end{tabular}

Tabel 3 Kategori Taraf Pencapaian Belajar Siswa

\begin{tabular}{ccc}
\hline No & Nilai interval & Kategori \\
\hline 1 & $85-100$ & Sangat baik \\
\hline 2 & $75-84$ & Baik \\
\hline 3 & $60-74$ & Cukup \\
\hline 4 & $50-59$ & Kurang \\
\hline 5 & $0-49$ & Sangat kurang \\
\hline
\end{tabular}

Tabel 4 Klasifikasi Kemampuan Siswa

\begin{tabular}{|c|c|c|c|}
\hline No & Nilai & Frekuensi & Presentase $\%$ \\
\hline 1 & Nilai $75 \mathrm{ke}$ atas & & \\
\hline 2 & Nilai 74 ke bawah & & \\
\hline & Jumlah $(\mathrm{N})$ & & \\
\hline
\end{tabular}

Penggunaan metode sugesti imajinasi ditetapkan berdasarkan ketentuan bahwa jika jumlah siswa mencapai $75 \%$ yang mendapat nilai $<75$ dianggap tidak berpengaruh. Apabila jumlah siswa mencapai $75 \%$ yang mendapat nilai $>75$ dianggap berpengaruh.

Teknik analisis data yang digunakan dalam penelitian ini adalah sebagai berikut.

1. Analisis Statistik Deskriptif

Data yang diperoleh melalui teknik tes dianalisis dengan menggunakan teknik statistik deskriptif, dengan skala penilaian 10-100. Teknik tersebut adalah sebagai berikut.

a. Mengubah skor menjadi nilai dengan rumus: $N=\frac{\text { SkorPerolehan }}{\text { SkorMaksimal }} \times 100$

Keterangan rumus:

$\mathrm{N}=$ Nilai jadi

$\mathrm{SP}=$ Skor Perolehan

$\mathrm{SM}=$ Skor Maksimal

(Depdiknas, 2006)

b. Analisis Statistik Inferensial dengan Melakukan Uji Hipotesis

Melakukan uji hipotesis dengan statistik inferensial parametrik (t-tes) dengan penghitungan statistik lewat komputer menggunakan program SPSS 21 for Windows. Dalam pengujian statistik, hipotesis dinyatakan sebagai berikut :

$\mathrm{H}_{\mathrm{o}}$ : th $\leq \mathrm{tt}$ lawan $\mathrm{H}_{1}:$ th $\geq \mathrm{tt}$

Untuk menerima hipotesis alternatif $\left(\mathrm{H}_{1}\right)$ apabila $\mathrm{t}$ hitung $<\mathrm{t}$ tabel dan secara otomatis hipotesis nol $\left(\mathrm{H}_{0}\right)$ menolak hipotesis alternatif 
$\left(\mathrm{H}_{1}\right)$, dan sebaliknya jika $\mathrm{t}$ hitung $>\mathrm{t}$ tabel maka secara otomatis menolak $\mathrm{H}_{0}$ dan menerima $\mathrm{H}_{1}$.

\section{HASIL DAN PEMBAHASAN}

Data yang diperoleh dari hasil menulis cerpen siswa kelas VIII SMP Negeri 5 Panca Rijang baik kelompok eksprimen maupun kelompok kontrol dianalisis sesuai dengan teknik analisis data yang telah diuraikan pada bab III yaitu, menggunakan analisis statistik deskriptif dan analisis statistik inferensial. Adapun penyajiannya dapat dilihat sebagai berikut.

1. Analisis Statistik Deskriptif

a. Analisis Nilai Tes Menulis Cerpen Kelompok Kontrol

Tabel 5 Skor dan Nilai Menulis Cerpen Siswa Kelompok Eksperimen

\begin{tabular}{cccc}
\hline No. & $\begin{array}{c}\text { Kode } \\
\text { Penomoran }\end{array}$ & Skor & Nilai \\
\hline 1 & 2 & 3 & 4 \\
\hline 1. & 01 & 90 & 90 \\
\hline 2. & 02 & 70 & 70 \\
\hline 3. & 03 & 84 & 84 \\
\hline 4. & 04 & 87 & 87 \\
\hline 5. & 05 & 75 & 75 \\
\hline 6. & 06 & 90 & 90 \\
\hline 7. & 07 & 92 & 92 \\
\hline 8. & 08 & 84 & 84 \\
\hline 9. & 09 & 84 & 84 \\
\hline 10. & 010 & 75 & 75 \\
\hline 11. & 011 & 76 & 76 \\
\hline 12. & 012 & 80 & 80 \\
\hline 13. & 013 & 72 & 72 \\
\hline 14. & 014 & 80 & 80 \\
\hline 15. & 015 & 75 & 75 \\
\hline 16. & 016 & 90 & 90 \\
\hline 17. & 017 & 77 & 77 \\
\hline 18. & 018 & 75 & 75 \\
\hline 19. & 019 & 80 & 80 \\
\hline
\end{tabular}

Tabel 6 Klasifikasi Kemampuan Menulis Cerpen (Kelompok Eksperimen)

\begin{tabular}{ccccc}
\hline No & $\begin{array}{c}\text { Nilai } \\
\text { Interval }\end{array}$ & Frekuensi & Presentase & Kategori \\
\hline 1 & $85-100$ & 5 & $26,3 \%$ & $\begin{array}{c}\text { Sangat } \\
\text { Baik }\end{array}$ \\
\hline 2 & $75-84$ & 12 & $63,1 \%$ & Baik \\
\hline 3 & $60-74$ & 2 & $10,5 \%$ & Cukup \\
\hline 4 & $50-59$ & 0 & $0 \%$ & Kurang \\
\hline 5 & $0-49$ & 0 & $0 \%$ & $\begin{array}{c}\text { Sangat } \\
\text { kurang }\end{array}$ \\
\hline
\end{tabular}

Tabel 7 Distribusi dan Persentase Kriteria Ketuntasan Hasil Belajar Kelompok Eksprimen

\begin{tabular}{cccc}
\hline Nilai & Kategori & Frekuensi & Presentase\% \\
\hline$\geq 75$ & Tuntas & 17 & $89,4 \%$ \\
\hline$\leq 75$ & Tidak Tuntas & 2 & $10,5 \%$ \\
\hline & Jumlah $(\mathrm{N})$ & 19 & $100 \%$ \\
\hline
\end{tabular}

b. Analisis Nilai Tes Menulis Cerpen Kelompok Kontrol

Tabel 8 Skor dan Nilai Menulis Cerpen Kelas Kontrol

\begin{tabular}{|c|c|c|c|}
\hline No & Kode Penomoran & Skor & Nilai \\
\hline 1 & 2 & 3 & 4 \\
\hline 1. & 01 & 83 & 83 \\
\hline 2. & 02 & 87 & 87 \\
\hline 3. & 03 & 60 & 60 \\
\hline 4. & 04 & 60 & 60 \\
\hline 5 & 05 & 76 & 76 \\
\hline 6. & 06 & 75 & 75 \\
\hline 7. & 07 & 65 & 65 \\
\hline 8. & 08 & 60 & 60 \\
\hline 9. & 09 & 76 & 76 \\
\hline 10. & 010 & 71 & 71 \\
\hline 11. & 011 & 85 & 85 \\
\hline 12. & 012 & 70 & 70 \\
\hline 13. & 013 & 72 & 72 \\
\hline 14. & 014 & 80 & 80 \\
\hline 15. & 015 & 75 & 75 \\
\hline 16. & 016 & 60 & 60 \\
\hline 17. & 017 & 72 & 72 \\
\hline 18. & 018 & 70 & 70 \\
\hline 19. & 019 & 70 & 70 \\
\hline 20. & 020 & 75 & 75 \\
\hline
\end{tabular}

Tabel 9 Klasifikasi Kemampuan Menulis Cerpen Siswa (Kelompok Kontrol)

\begin{tabular}{ccccc}
\hline No & $\begin{array}{c}\text { Nilai } \\
\text { Interval }\end{array}$ & Frekuensi & Presentase & Kategori \\
\hline 1 & $85-100$ & 5 & $26,3 \%$ & Sangat baik \\
\hline 2 & $75-84$ & 12 & $63,1 \%$ & Baik \\
\hline 3 & $60-74$ & 2 & $10,5 \%$ & Cukup \\
\hline 4 & $50-59$ & 0 & $0 \%$ & Kurang \\
\hline 5 & $0-49$ & 0 & $0 \%$ & Sangat kurang \\
\hline
\end{tabular}

Tabel 10 Distribusi dan Persentase Kriteria Ketuntasan Hasil Belajar Kelas Kontrol

\begin{tabular}{cccc}
\hline Nilai & Kategori & Frekuensi & Persentase\% \\
\hline$\geq 75$ & Tuntas & 9 & $45 \%$ \\
\hline$\leq 75$ & TidakTuntas & 11 & $55 \%$ \\
\hline & Jumlah (N) & 20 & $100 \%$ \\
\hline
\end{tabular}

2. Analisis Statistik Inferensial dengan Uji Hipotesis

Tabel 11 Group Statistics

\begin{tabular}{|c|c|c|c|c|}
\hline Kelas & $\mathrm{N}$ & Mean & $\begin{array}{c}\text { Std. } \\
\text { Deviation }\end{array}$ & $\begin{array}{l}\text { Std. } \\
\text { Error }\end{array}$ \\
\hline
\end{tabular}




\begin{tabular}{llllll}
\hline & & & & & \multirow{2}{*}{ Mean } \\
\hline \multirow{2}{*}{ Nilai } & 1 & 19 & 80.8421 & 6.73517 & 1.54515 \\
\cline { 2 - 6 } & 2 & 20 & 72.1000 & 8.19435 & 1.83231 \\
\hline
\end{tabular}

Pada tabel output grup statistic diketahui jumlah data hasil belajar untuk kelas VIII 1 yaitu sebanyak 19 siswa, sementara untuk kelas VIII 2 yaitu sebanyak 20 siswa. Nilai rata-rata hasil menulis cerpen siswa atau mean untuk kelas VIII 1 yaitu sebesar 80,84 sedangkan kelas VIII
2 sebesar 72,10. Sementara standar deviasi masing-masing yakni 6,73 dan 8,19. Standar error mean pada masing- masing kelas yaitu 1.54 dan 1,83. Dengan demikian secara deskriptif statistik dapat disimpulkan ada perbedaan rata-rata hasil menulis cerpenantara kelas VIII 1 dan kelas VIII 2.

Selanjutnya untuk membuktikan apakah perbedaan tersebut berarti signifikan (nyata) atau tidak maka kita perlu menafsirkan output independent samples test.

Tabel 12 Independent Samples Test

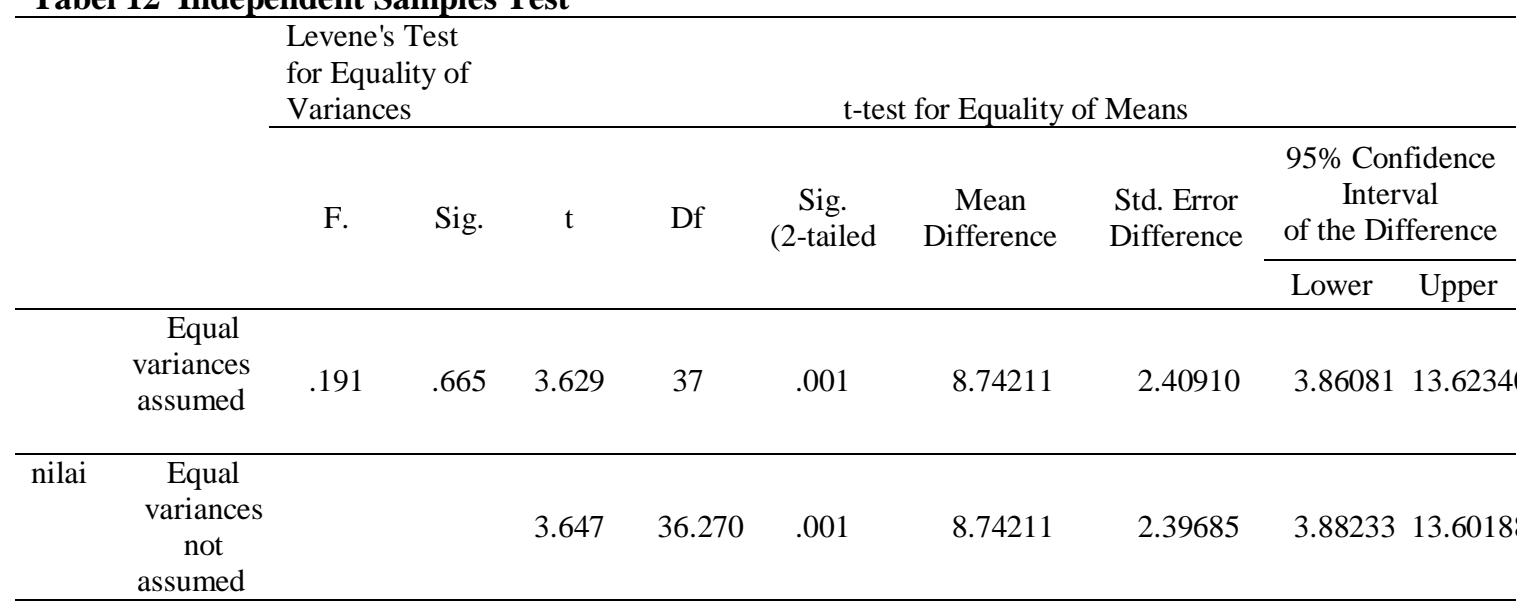

Setelah memperhatikan karakteristik variabel yang telah diteliti dan persyaratan analisis, selanjutnya dilakukan pengujian terhadap hipotesis. Untuk keperluan hipotesis digunakan statistika inferensial dengan bantuan program Statistical Package for Social Science (SPSS) versi 21 yaitu statistika uji t, dalam hal ini Independent sample $\mathrm{t}$ test (uji $\mathrm{t}$ sampel independent). Kriteriapengujiaannya adalah hipotesis $\mathrm{H} 0$ diterima apabila $\mathrm{t}$ hitung $<\mathrm{t}$ tabel dan $\mathrm{H} 0$ ditolak apabila $\mathrm{t}$ hitung $>\mathrm{t}$ tabel dan artinya $\mathrm{H} 1$ diterima.

Pada output SPSS Independent Sample Test diketahui bahwa nilai t hitung sebesar 3,629 dengan df 37. Adapun nilai $\mathrm{t}$ tabel pada df 37 yaitu 2,026. Berdasarkan dari data tersebut yaitu 3,629 2 2,026 maka Ho ditolak dan H1 diterima sehingga dapat dikatakan bahwa terdapat perbedaan signifikan hasil belajar menulis cerpen dengan menggunakan metode sugesti imajinasi dan metode konvensonal pada siswa kelas VIII SMP Negeri 5 Panca Rijang dengan rata-rata hasil belajar kelas ekperimen adalah 80 dan rata-rata kelas kontrol adalah 72 .

\section{PEMBAHASAN}

Hasil analisis data menunjukkan bahwa nilai rata-rata yang diperoleh kelompok eksprimen adalah 80 dengan persentase ketuntasan $89,4 \%$ sedangkan pada kelompok kontrol menunjukkan bahwa nilai rata-rata yang diperoleh yaitu 72 dengan persentase ketuntasan $45 \%$. Adapun hasil analisis statistik inferensial dengan melakukan uji hipotesis yaitu berdasarkan tabel output Group statistik dengan menggunakan SPSS 21 diketahui jumlah data belajar untuk kelompok eksprimen dengan nilai rata-rata sebesar 80,84 sedangkan kelompok kontrol dengan nilai rata-rata sebesar 72,10 dengan standar deviasi masing-masing yakni 6,73 dan 8,19 dan standar error mean pada masing-masing kelas yaitu 1,54 dan 1,03. Adapun output independent sample t-test 
diketahui bahwa nilai t hitung sebesar 3,629 dengan Df 37 dengan nilai t tabel yaitu 2,026 sehingga dapat disimpulkan 3,629 $\geq 2,026$ maka $\mathrm{H} 0$ ditolak dan $\mathrm{H} 1$ diterima sehingga ada perbedaan secara signifikan hasil belajar pada kelompok eksperimen dengan menggunakan metode sugesti imajinasi dan kelompok kontrol dengan metode konvensional.

Pada hasil yang dipaparkan di atas penggunaan metode sugesti imajinasi berpengaruh dalam pembelajaran menulis cerpen siswa kelas VIII SMP Negeri 5 Panca Rijang. Jika dibandingkan dengan penelitian terlebih dahulu yang relevan dengan penelitian ini yang pertama adalah penelitian yang dilakukan oleh Pebriana (2017), dengan Judul Pembelajaran Menulis Puisi Bebas dengan Menggunakan Metode Sugesti Imajinasi pada Kelas V SDN 001 Salo. Pada penelitian terdahulu materinya adalah menulis puisi bebas sedangkan materi dalam penelitian ini yaitu menulis cerpen. Dari segi hasil kedua penelitian ini sama-sama memberikan pengaruh meskipun materi penelitiannya berbeda.

Penelitian kedua dilakukan oleh Erlista (2018), dengan judul Peningkatan Keterampilan Menulis Puisi Menggunakan Metode Sugesti Imajinasi dengan Media Videoklip Lagu Siswa Kelas VIII H SMPN 4 Semarang. Persamaan penelitian Erlista (2018), dengan penelitian ini, terletak pada metode pembelajaran yang digunakan yaitu metode sugesti imajinasi. Pada penelitian Erlista (2018) metode sugesti imajinasi mampu meningkatkan keterampilan menulis puisi. Dalam penelitian ini metode sugesti imajinasi berpengaruh dalam pembelajaran menulis cerpen.

Selanjutnya penelitian Ariati (2018), dengan judul Penerapan Metode Sugesti Imajinasi untuk Meningkatkan Minat dan Hasil Belajar Menulis Cerpen Siswa Kelas IX SMP Negeri 3 Selat. Persamaan penelitian ini dengan penelitian Ariati (2018), terletak pada materi dan metode pembelajaran yang digunakan yaitu metode sugesti imajinasi dan materi yang diajarkan yaitu menulis cerpen. Pada penelitian ini metode sugesti imajinasi mampu meningkatkan minat dan hasil belajar menulis cerpen. Dalam penelitian ini metode sugesti imajinasi berpengaruh dalam pembelajaran menulis cerpen.
Sesuai hasil perhitungan analisis data, dapat dikatakan bahwa penggunaan metode sugesti imajinasi sangat berpengaruh dalam pembelajaran menulis cerpen siswa kelas VIII SMP Negeri 5 Panca Rijang. Sugesti imajinasi adalah metode pembelajaran menulis dengan cara memberikan sugesti lewat lagu untuk merangsang imajinasi siswa (Trimatra, 2015: 3). Dalam hal ini, lagu digunakan sebagai penciptaan suasana sugestif, stimulus, dan sekaligus menjadi jembatan bagi siswa berupa kemampuan melihat gambaran-gambaran kejadian tersebut dengan imajinasi-imajinasi dan logika yang dimiliki lalu mengungkapkan kembali dengan menggunakan simbol-simbol verbal. Hal tersebut dibuktikan oleh hasil analisis statistik inferensial dengan melakukan uji hipotesis yaitu berdasarkan tabel output Group statistik dengan menggunakan SPSS 21 diketahui jumlah data belajar untuk kelompok eksprimen dengan nilai rata-rata sebesar 80,84 sedangkan kelompok kontrol dengan nilai ratarata sebesar 72,10 dengan standar deviasi masing-masing yakni 6,73 dan 8,19 dan standar error mean pada masing-masing kelas yaitu 1,54 dan 1,03. Dan hasil output independent sample ttest yaitu nilai t hitung sebesar 3,629 dengan Df 37 dengan nilai $\mathrm{t}$ tabel yaitu 2,026 sehingga dapat disimpulkan 3,629 $\geq 2,026$ maka $\mathrm{H} 0$ ditolak dan $\mathrm{H} 1$ diterima sehingga ada perbedaan secara signifikan hasil belajar pada kelompok eksperimen dengan menggunakan metode sugesti imajinasi dan kelompok kontrol dengan metode konvensional

\section{PENUTUP}

Berdasarkan analisis data menunjukkan nilai rata-rata kelompok eksprimen sebesar 80,84 sedangkan kelompok kontrol sebesar 72,10. Pada output SPSS Independent Sample Test diketahui bahwa nilai t hitung sebesar 3,629 dengan df 37. Adapun nilai t tabel pada df 37 yaitu 2,026. Berdasarkan dari data tersebut yaitu 3,629 2 2,026 maka Ho ditolak dan H1 diterima. Maka penggunaan metode sugesti imajinasi berpengaruh dalam pembelajaran menulis cerpen siswa kelas VIII SMP Negeri 5 Panca Rijang. 


\section{DAFTAR PUSTAKA}

Ariati, N. N. (2020). Penerapan Metode Pembelajaran Sugesti-Imajinasi Untuk Meningkatkan Minat Dan Hasil Belajar Menulis Cerpen Siswa. Cetta: Jurnal Ilmu Pendidikan, 3(1).

Depdiknas. 2006. Kurikulum Tingkat Satuan Pendidikan. Jakarta: Depdiknas.

Erlista, A. (2018). Peningkatan Keterampilan Menulis Puisi Menggunakan Metode Sugesti Imajinasi dengan Media Videoklip Lagu. Jurnal Pendidikan Bahasa dan Sastra Indonesia, 7(1), 7-13.

Nurgiyantoro, Burhan. 2001. Penilaian dalam Pengajaran Bahasa dan Sastra. Yogyakarta: BPEE.
Sugiyono. 2014. Metode Penelitian Kuantitatif, Kualitatif dan $R \& D$. Bandung: Alfaberta.

Suparno, dan Yunus Muhammad. 2007. Keterampilan Dasar Menulis. Jakarta: Universitas Terbuka.

Trimantara, P. (2005). Metode sugestiimajinasi dalam pembelajaran menulis dengan media lagu. Jurnal Pendidikan Penabur, 5(4), 1-15.

Pebriana, P. H. (2018). Pembelajaran Menulis Puisi Bebas dengan Menggunakan Metode Sugesti Imajinatif pada Kelas V SDN 001 Salo. EduHumanioral Jurnal Pendidikan Dasar Kampus Cibiru, 10(1), 1-7. 